\title{
SELF ESTEEM AND ITS RELATIONSHIP TO LIFE SATISFACTION AND EMOTIONAL INTELLIGENCE: AN EXPLORATORY STUDY AMONGST SECONDARY
}

\author{
AMIT KUMAR $^{1}$ \& DAYAL SANDHU ${ }^{2}$ \\ ${ }^{1}$ Research Scholar, Dayalbagh Educational Institute, Agra, India \\ ${ }^{2}$ Assistant Professor, Faculty of Education, GLA University, Mathura, India
}

\begin{abstract}
This research was planned to ascertain to explore the relationship of self esteem towards life satisfaction and emotional Intelligence amongst secondary school teachers of Mathura district (U.P.). The research employed normative survey method and convenience sampling technique for the purpose of investigation. The investigator used for measuring selfesteem,emotional intelligence and life satisfaction, Rosenberg Self-esteem Scale by Rosenberg (1965), Emotional Intelligence Scale by Hyde and Pethe (2001) and Life Satisfaction Scale by Alam and Srivastava (2002) respectively. This research employed Pearson Product Moment Correlation Coefficient to obtain the results. The research revealed that there is statistical significant and positive relationship of self esteem with life satisfaction and emotional intelligence amongst secondary school teachers of Mathura district (U.P.), India.
\end{abstract}

KEYWORDS: Self Esteem, Life Satisfaction, Emotional Intelligence Normative Survey

Received: Jun 01, 2020; Accepted: Jun 20, 2020; Published: Jul 10, 2020; Paper Id.: IJMPERDJUN2020273

\section{INTRODUCTION}

Education is measured to be the mainly influential mechanism for bringing about the preferred changes in the public. In any liberated Nation, education is stimulating with the twin accountability of securing the country's conventional ethnicity, initiating vigorous social change and expanding rejuvenation. The excellence of any country relies upon the quality of its citizens. The excellence of the citizens in a significant sense dependent on the worth of their education. The excellence of their education depends upon excellence of their teacher educators and the excellence of educators relies tremendously upon the excellence of their individual education, together that segment which before comes after their access into their vocation. A educator is a important constituent of school supervision that lies at the most significant tip in the educational procedure. It is educator who is most powerful as far as the excellence of education is alarmed. Educators change perpetuity, they can by no means inform when their pressure stops. An educator position is tremendously significant in determining, altering the behavior, tastes, etiquette and the temperament of the pupil. Educators vigorously distribute the accountability for reimplementing a societal regulates the ethics and conventional beliefs, which are life form battered by the rush of new thoughts and practices. Educators are the spine of the social order. They are forever anxious with mental, physical and spiritual development of the children who are good quality citizen and prospective leaders of prospective future. Tomorrow's homeland will relies upon the kind of society taught and learned nowadays in temples of knowledge. Consequently, it is essential to stay mentally hale and hearty. On the other hand, if the educators 
are subjected to extreme pressure and sprain, they cannot uphold their mental equilibrium. If not dealt critically, educators' self-esteem and emotional intelligence, the main correlates, might persuade their life satisfaction, unfavorably.

\section{Self Esteem}

The fundamental notion of theory of self-esteem is that each person has an internal value. These internal principles make them experience, they are noteworthy, as individuals, one frequently seek to advance that value. It is associated to the ego and natives with low self-esteem asserted to be distress from a low standard multipart. In common word, natives with modest self-esteem usually sense their existence commendable, even as those with little self-esteem sense they are fewer creditable of good quality life. Rosenberg (1965) define that the "self is constituted of two elements identity indicating cognitive variables and self-esteem means affective variables". The cognitive variable includes perception and interpretation of sense. Rosenberg described self-esteem as the subjective life of the human being, sentiments, conduct and in principal view of the human being.

\section{Life Satisfaction}

Life satisfaction is well thought-out as a vital variable in younger, grown-up as well as aged persons. Quite a few explorers have considered the factors of life satisfaction. Positive associations have constantly been given among life satisfaction, socio economic position, professed sufficiency of income and seeming health position. It is normally described as the extent to which persons evaluates the superiority of their lives positively and it be able to be balanced with contentment. Life satisfaction is the final objective that all individual beings are determined to attain. The life satisfaction is notion that can denote lots of diverse belongings to diverse persons. Life satisfaction is generally regarded to as pleasure approaching from the accomplishment of a requirement or desires and as such is the reason or wealth of pleasure.

\section{Emotional Intelligence}

A major psychological conception which occupied the intellect of educators is recognized as emotional intelligence. The source of emotional intelligence has been evolved from social intelligence. In the year 1920, Throndike was one who introduced the word emotional intelligence. The outline of emotional intelligence was arrive into radiance through Gardner theory of multiple intelligence in the year 1983. This theory is separated into two factors (i) intra-intelligence and (ii) intrapersonal intelligence. In the vicinity of scholastic the expression emotional intelligence arrive into subsistence by the job of Wayne (1985) and said it includes connecting creativeness to terror, hurt and wish and provides supervision on how to transmit to them in emotionally intellectual habits. Salovey and Mayer (1990) defined it as the "ability to monitor one own and others feelings and emotions, to discriminate among them and to use this information to guide one thinking and action".

\section{OBJECTIVES}

- To study relationship of self-esteem with life satisfaction and emotional intelligence amongst married secondary school teachers.

\section{HYPOTHESIS}

There will be no significant difference in relationship of self esteem with life satisfaction and emotional intelligence amongst married secondary school teachers. 


\section{DELIMITATIONS OF RESEARCH}

- The current research is delimited to Mathura district of Uttar Pradesh.

- The study is confined to married secondary school teachers of Mathura district, Uttar Pradesh.

\section{Selection of Sample:}

The sample for the research constituted of 200 married feminine secondary school educators from governments and private secondary schools from Mathura district (U.P.) selected through convenience sampling technique.

\section{Research Instrument}

For assessing the variables like self-esteem, emotional intelligence and life satisfaction, Rosenberg Self-esteem Scale by Rosenberg (1965), Emotional Intelligence Scale by Hyde and Pethe (2001) and Life Satisfaction Scale by Alam and Srivastava (2002) were utilized in that order.

\section{Statistical Techniques}

Pearson Product Moment Coefficient of correlation was useful to discover the correlation amongst secondary school teachers with respect to self-esteem, emotional intelligence and life satisfaction.

\section{RESULTS AND DISCUSSIONS}

The Pearson product moment coefficients of correlation were computed to confirm the anticipated hypothesis. Matrix of Correlation in the Table-1 was produced which exhibits intercorrelation amongst the anticipated variables.

Table 1: Matrix of Correlation Exhibiting Relationship between Self Esteem, Emotional Intelligence and Life Satisfaction

\begin{tabular}{|l|c|c|c|c|c|}
\hline \multicolumn{1}{|c|}{ Variables } & Mean & $\begin{array}{c}\text { Standard } \\
\text { Deviation }\end{array}$ & Self Esteem & $\begin{array}{c}\text { Emotional } \\
\text { Intelligence }\end{array}$ & Life Satisfaction \\
\hline Self Esteem & 17.32 & 6.13 & 1 & & \\
\hline Emotional Intelligence & 126.73 & 28.68 & $0.24^{* *}$ & 1.0 & 1.0 \\
\hline $\begin{array}{l}\text { Life Satisfaction } \\
* * \mathbf{P}<.01 \text { significance level }\end{array}$ & 38.50 & 7.83 & $0.50^{* *}$ & $0.73^{* *}$ & \\
\end{tabular}

The correlation matrix in the table 1 denotes that life satisfaction and self-esteem scores are positively interrelated $(r=0.50)$.The hypothesis reveals that life satisfaction would be positively correlated with self-esteem was assisted by the interpreted results. There was originated to be positive association amongst self-esteem and emotional intelligence scores (r $=0.24)$.It is obvious that with the enhance in scores of self esteem there is additional percentage increase in emotional intelligence.

In perspective of self-esteem, all educators with high life satisfaction stated that they perform without help and presume their accountability. In comparison of educators who occupies low life satisfaction reported that they sense that additional educators do not value them and feel powerless and easily influenced by others. In relation to emotional intelligence, all teachers who have high life satisfaction asserted they convey their sentiment liberally and do not change their judgment, they also stated they are not conquered by pessimistic emotions, meanwhile who have low life satisfaction stated that they usually do not take accountability for their individual feelings but hold responsible on others. They also 
asserted that they forever blame others for their have possession of feelings and now and then they diminish their own sentiments.

\section{CONCLUSIONS}

On culmination of the conclusion, it may perhaps be culminated that there is positive co relationship amongst self-esteem and emotional intelligence, and self-esteem was also positively correlated to life satisfaction. On contrary, there is significant positive co relationship was originate amongst emotional intelligence and life satisfaction.

\section{REFERENCES}

1. Abraham, A., \& Rebecca, S. (2000). The role of job control as a moderator of emotional dissonance and emotional intelligenceoutcome relationships. Journal of Psychology: Interdisciplinary and Applied, 134 (2), 169-184.

2. Abraham, G. (2005). Role conflict and perceptions of gender roles: The $\neg$ case of Israel. Journal of Sex-Role, 32 (3), $251-270$.

3. Acosta, A. (2006). Gender role conflict and psychological distress. $\neg$ Journal of Social Psychology, 66 (11), 59-61.

4. Ahan, H., Tekin, M., $\neg \&$ Yarar, N. (2012). Examination of self-efficacy and life satisfaction levels of students receiving education in school of physical education and sports. Journal of World Academy Science, Engineering and Technology, 66 (1), 15-21.

5. Akbari, J.A. (2012). Life satisfaction and stress among working and non $\neg$ working women. Indian Journal of Research Paripex, $9(1), 174-178$.

6. Alam, Q. G., ᄀ\& Srivastava, R. (2001). Life Satisfaction Scale. Agra: National Psychological Corporation.

7. Alston, J. P., $\neg \&$ Dudley, J. (1973). Age occupation and life satisfaction gerontologists. Journal of Social Psychology, 13 (2), $58-61$.

8. Altınok, V. (2011). The relationship between job satisfaction of $\neg$ academicians and life time satisfaction. African Journal of Business Management, 5 (7), 2563-2571.

9. Anisa, M. (2006). The marital construction of gender through work and $\neg$ family decisions: A qualitative analysis. Journal of Marriage and the Family, 58 (4), 91-100.

10. Anne, D. (2006). A gleam in the eye an investigation: Self-esteem of high $\neg$ school teachers in the Australian Capital Territory government schools. Journal of Educational Psychology, 25 (2), 122-125.

11. Anozie, M. (2007). Do Africa-American women learners perform better $\neg$ academically than African? Journal of Social Psychology, 68 (9), 11-19.

12. Arslan, C., Hamarta,E., $\neg \&$ Uslu,M. (2010).The relationship between conflict communication, self-esteem and life satisfaction in university students. Educational Research and Reviews, 5 (1), 31-34.

13. Azar, S. (2006). Relationship between quality of life, hardiness, selfefficacy and self-esteem amongst employed and unemployed married $\neg$ women in Zabol. Journal of Social Psychology, 30 (6), 158-165.

14. Aziz, M. (2004). Role stress among women in the Indian information $\neg$ technology sector. Women in Management Review, 17 (7), 322-333. 
15. Baron, R. (1997). The Emotional Quotient Inventory (EQ-i): A Test of $\neg$ Emotional Intelligence. Toronto: Multi-Health Systems.

16. Barrington, T. M. (1963). The introduction of selected Educational $\neg$ practices into teacher-college and their Laboratory School. New York: Bureau of Publication Teacher College, C.U.

17. Bhardwaj, A., ᄀ\& Agrawal, G. (2013). Gender difference in pre adolescent's self-esteem. International Journal of Social Science \& Interdisciplinary Research, 2(8), 114-119.

18. Bhattacharjee, A. (2010). Self-esteem of tribal and non tribal college $\neg$ students of Tripura. Indian Journal of Psychological Science, 1 (1), 146- 155.

19. Bishay, A. (2007). Teacher motivation and job satisfaction. Journal of $\neg$ Educational Psychology, 3 (10), 147-154.

20. Blascovich, J., \& Tomaka, J. (1991). Measures of self-esteem. In J. P. Robinson, P. R. Shaver, \& L. S. Wrightsman (Eds.) Measures of personality and social psychological attitudes, Volume I. San Diego, CA: Academic Press.

21. Boles, J., Johnston, W., \& Joseph, F. (1997).Role stress, work-family conflict and emotional exhaustion: inter-relationships and effects on some work-related consequences. The Journal of Personal Selling and Sales Management,17(1),17-28.

22. Bower, G. H. (1981). Mood and memory. American Psychologist, 36 (1), $\neg 129-148$. Branden, N. (1969). The Psychology of Self-Esteem. New York: Bantam. Brockner, J. (1988). Self-esteem at work. Lexington MA: England $\neg$ Lexington Books.

23. Brown, J.T., \& Sumner, K. (2013).The work-family interface among school psychologists and related school personnel: a test of role conflict iv and expansionist theories. Journal of Applied Social Psychology, 55(6), 605-613.

24. Buck, R. (1985). Motivation and Emotion. In D. Hothersall, Psychology. Columbus, Ohio: Charles E. Merrill Publishing house.

25. UPRETI, RASHMI, and SEEMA SHARMA. "A STUDY OF SELF ESTEEM AND ITS RELATIONSHIP WITH THE ADJUSTMENT OF ORPHAN AGE-REARED, SINGLE PARENT FAMILY-REARED AND INTACT FAMILY-REARED ADOLESCENTS." International Journal of Educational Science and Research 8.2 (2018): 41-50.

26. Suresh, D., and Vincent E. Emore. "Comparison of the Role Participation and Life Satisfaction of Middle-Age People with Stroke and People Without Stroke." International Journal of Medicine and Pharmaceutical Science (IJMPS) 8.1 (2018): 25-32.

27. Hsu, Yuan-Ho. "Exploring Predictors of Subjective Life Satisfaction in an Aging Economy:: An Empirical Investigation of Taiwan." International Journal of Humanities, Arts, Medicine and Sciences 5.5 (2017): 95-110.

28. Kulkarni, S. H. R. A. D. D. H. A. "Emotional intelligence: An essential part of leadership effectiveness. "IMPACT: International Journal of Research in Business Management 2.1 (2014): 13-22.

29. THAVARAJ, H. SAMUEL. "Identifying the Association between Profile Variables and the Level of Emotional Intelligence among Bank Branch Managers in Madurai District, Tamilnadu, South India." Tamilnadu, South India (December 15, 2015) (2015).

30. Panth, Mukesh Kumar, and Akanksha Patel. "A Comprative Study of Emotional Intelligence and Intelligence Quotient in Between Rural and Urban Under Graduate Boys and Girls."

31. Altamirano, Michael A. "A Comprehensive Approach to Emotional Intelligence: A Theory in Relation to Online Learning." 
